\title{
Classroom Teachers' Opinions on Science Laboratory Practices
}

\author{
Nil Duban ${ }^{1, *}$, Bülent Aydoğdu', Aslı Yüksel ${ }^{2}$ \\ ${ }^{1}$ Faculty of Education, Afyon Kocatepe University, Turkey \\ ${ }^{2}$ Faculty of Education, Alanya Alaaddin Keykubat University, Turkey
}

Copyright $\subseteq 2019$ by authors, all rights reserved. Authors agree that this article remains permanently open access under the terms of the Creative Commons Attribution License 4.0 International License

\begin{abstract}
Open-ended and inquiry-based experiments will make students more active in the learning environment, and so they play an active role in solving the problem. So, it is expected that especially classroom teachers will be more active in the laboratory environment. In this context, opinions of the classroom teachers about the science laboratory practices seem important. From this point of view, the aim of the current research was to get the opinions of the classroom teachers on science laboratory practices. This research was carried out with phenomenology design within the scope of qualitative research methods. The classroom teachers were participants in the research group of the current study created as a type of sampling method. Interview technique was used and individual semi-structured interviews with participants were conducted. The data obtained in the study were evaluated by qualitative data analysis. As a result of the analysis made in this research aiming to determine the opinions of the classroom teachers about science laboratory practices, the main topics of science laboratory practices are processing of the science course, availability of the laboratory, expectations about the laboratory characteristics, teachers' laboratory education, benefits of experimenting in science class. It has been pointed out that some troubles are derive from the way of using laboratory in science course. Some of the class teachers stated that there was no science laboratory in the schools, but some of them stated that some materials were available. They added that even though schools had not got laboratories but the teachers were forced to use the materials actively because these materials were present in the storage rooms. In the light of the current research, the teachers wanted to be in a primary school, and in the context of the properties of the laboratory, it has been found that materials are available, relevant images are on the walls, and there is a responsible laboratory teacher in the science laboratories. In this research, it has been stated that safety measures have been taken during the laboratory practices in primary school. It has been emphasized that safety precautions to be taken in the laboratory includes the use of a number of
\end{abstract}

tools for safety (gloves, goggles, and so on) and the enhancement of teacher supervision in the laboratory have been.

Keywords Classroom Teachers, Elementary Science Education, Laboratory Practices

\section{Introduction}

One of the main objectives of science teaching is to train individuals who will be able to adapt to rapidly changing and developing age and benefit from the latest technological innovations [1]. Teachers have great responsibilities to reach this goal. In short, in this process, teacher should be in the role of a guide that shares the importance of science teaching and the responsibility and enthusiasm of reaching scientific knowledge and at the same time guides the research process in its class [2]. Students will play a more active role in such learning environments. It is known that science laboratories play an extremely important role in students' active participation in the learning process [3]. Laboratory practices play a central role to fill the gap between theory and practice [4]. Laboratory applications have been stated to help students define the concepts of science in a more comprehensive and meaningful manner [5]. Laboratories have long been regarded as an important component in science education [6]. In this context, teachers should give more weight to laboratory work so that students can correctly acquire the science concepts and do not have misconceptions [7]. The reason is that laboratory practices have an important effect on students to learn science concepts [8]. As a result, it can be said that science laboratories have a central role in science education. Science educators have often stressed that more learning takes place thanks to laboratory activities [9]. Students gain direct experience by conducting experiments in laboratories [10]. Moreover, students' attitudes and achievements to science education 
evolve through laboratory teaching [11]. Furthermore, laboratory instruction improves students' ability in science education [3]. As a result, laboratory studies provide students with cognitive, affective, and psychomotor-based contributions [12].

It is very important for the techniques applied in a laboratory as well as for the laboratory use in science teaching. As is known, it is suggested that closed-ended experiments cannot contribute much to the meaningful learning of students [13]. As already known, most of the teacher candidates carry out close-ended laboratory practices throughout their university education [14]. As experiment guidelines defining the process step-step-step for teacher candidates are used in such laboratory practices, the students might be hindered from taking an active role. Likewise, most of the teachers tend to perform demonstration and close-ended experiment for the students [15]. The type of school the teachers work at (Anatolian High Schools, Vocational High Schools, and so on) is quite influential in teachers' carrying out close-ended or open-ended experiments. For example, while the teachers working at Anatolian High Schools prefer open-ended experiments, teachers working at Vocational High Schools prefer close-ended experiments [16]. In this sense, experimental techniques that students will be more active should be included in science courses. It is stated that especially open-ended experiments provide deeper understanding for the students [17]. One of the most significant ways to offer the students laboratory activities encouraging them to think more is to have them perform open-ended experiments [15]. Open-ended experiments are claimed to enable the students to make substantial explorations [18]. Students will have the opportunity and to provide opportunities to develop experiments related to their own work. In short, students have the ability to test their own teaching by shaping their own thoughts through open-ended experiments [19]. Similarly, the inquiry-based laboratory technique allows students to develop in many ways. In the inquiry-based experimental technique, students develop their solution proposals by identifying their own problems. In a laboratory where inquiry-based experiments are used, students are most likely to make real science. So, this method has an important place in science education [20]. As a result, open-ended and inquiry-based experiments will make students more active in the learning environment, and so, they play an active role in solving the real world problems. For this reason, it is expected that especially classroom teachers will be more active in the laboratory environment. In this context, the opinions of the classroom teachers about science laboratory practices seem important. From this point of view, the aim of the present research was to get the opinions of the class teachers on science laboratory practices.

The following questions were sought within the scope of the research objectives:
1. How do classroom teachers teach science lessons at primary school level?

2. What are the views of classroom teachers regarding the use of the laboratory in science lessons?

3. What are the expectations of classroom teachers for primary school laboratories?

4. What are the training situations of classroom teachers regarding the laboratory practices?

5. What are the opinions of classroom teachers on the importance of using the laboratory in science lessons?

6. What are the points that classroom teachers pay attention to while experimenting in a laboratory environment?

\section{Materials and Methods}

\subsection{Research Design}

This was a phenomenological design study as a qualitative method. In phenomenological design, the basic questions about the perceptions / experiences of this phenomenon and the circumstances in which these experiences of the phenomenon occur have been asked [21]. The participants can have perceptions and experiences of the phenomenon. In this study, the experiences of primary school classroom teachers about laboratory practices are being researched.

The phenomenological research method requires each participant to focus on his/her own world and to describe his/her experiences. The primary data collection method used by the researcher was an in-depth interview with open-ended questions [22]. In this study, the interview technique was used within the scope of phenomenological patterns in order to get the opinions of teachers on the science laboratory practices.

\subsection{Working Group}

The classroom teachers were participants in the working group of the current study. The maximum variation sampling was preferred as a sampling method according to the choices of the participants. Maximum variation sampling is a purposeful sampling strategy in which the researcher samples cases or individuals that differ on some characteristic or trait. This procedure requires a researcher to identify the characteristic and then find sites or individuals that display different dimensions of that characteristic [23]. The study group consisted of classroom teachers working at schools in different socioeconomic conditions with the aim to ensure a sample group with maximum variation sampling. In our country, teachers with higher seniority work at upper socioeconomic class schools in city centers whereas teachers with lower seniority work at schools located in rural areas and towns 
(medium and lower socioeconomic class). This study group consisted of a total of 18 teachers, including six class teachers working in public schools with low, medium, and high socioeconomic levels. Participants had professional experience varying between 8 and 30 years. So, the participants had different experiences from each other. Nine of the participants were female, and the other half were male.

\subsection{Data Collection}

The basic data gathering technique is the interview in the phenomenological design. In order to reveal the experiences and meanings of the phenomena, the interview technique offers the researchers the possibility of asking questions of interaction, flexibility and further discussion ([24] as cited [25]). This interview technique was used and individual semi-structured interviews with the participants were conducted.

\subsubsection{Internal Validity of the Research}

Within the scope of internal validity or credibility, expert review or expert revision is one of the strategies used. A good expert review should cover the examination of the raw data reviewed by another expert and should consider whether the findings are reasonable and logical [26]. In this study, with the use of the interview guide prepared by researchers, a pilot interview was made with a teacher apart from the participants. Then this recording was transcribed. A control check was asked from two experts, by reviewing the transcriptions of the interview questions to ascertain whether they were clear and understandable, whether they cover the subject discussed, and evaluating the possibility of whether it provides the required information. At the end of this review, the validity of the question items was determined, and thus, the final form of the interview guide was developed. After this operation was conducted, interviews with the participants were done. The recordings made during the interviews were resolved and the transcripts of them were put inside a word file by the researchers.

\subsubsection{The Reliability of the Research}

In qualitative research studies, reliability refers to the stability of multiple encoders' responses to the data set. Regarding the reliability, it is possible to use the inter-encoder consensus based on the use of multiple encoders to analyze the transcribed data [21]. Interview coding keys and interview transcripts were read separately by the researchers and a field expert (a science educator who also studies on qualitative research), and the necessary amendments were made to the topics with an "agreement" and "disagreement". For the reliability calculation of the study, the reliability formula proposed by [27] was used. As a result, the reliability of the research was calculated at $88 \%$. The fact that reliability calculations exceeded $70 \%$ is considered reliable for a research [27]. The result obtained here was considered reliable for this research.

\subsection{Analysis of Data}

The data obtained in the research were evaluated by qualitative data analysis. This type of data analysis includes coding the data, separating the text into smaller units (expression, sentence, or paragraph), assigning labels to each one, and grouping the codes into themes. The code label can be derived from the words of the participants, from the explanations created by the researcher, or from concepts used in social sciences [28]. Moreover, the findings obtained as a result of the research for the transferability of the work have also been directly supported by the quotations.

In the current study, the answers of each participant were examined in small paragraphs and labeled by writing codes next to each paragraph. The codes were grouped into the categories. The obtained categories were grouped in such a way to form a meaningful whole and sub-themes were formed. Thus, sub-themes and categories to be included under the main theme were prepared and shown on the table, and then each of them was explained in detail as the findings of the research. For the transmissibility of the study, the findings obtained as a result of the study were supported with direct quotations from the participants' statements. Code names were used while direct quotations from participants' opinions were presented during presentation of findings (such as Barış Teacher and Ayşe Teacher)

\section{Findings}

As a result of the analysis made in this research aiming to determine the opinions of the class teachers about the science laboratory practices, the main topics of science laboratory practices are processing of the science course, availability of the laboratory, expectations about the laboratory characteristics, teachers' laboratory education, benefits of experimenting in science class. Table 1 presents themes, sub-themes, and categories. 
Table 1. Sub-themes and categories under the main theme of science laboratory practices

\begin{tabular}{|c|c|c|}
\hline \multirow{5}{*}{ Science Laboratory Practices } & Teaching science lesson & $\begin{array}{r}\text { Experimenting in class } \\
\text { Taking advantage of the software } \\
\text { Watching videos about the experiment from the Internet } \\
\text { Teaching from textbook }\end{array}$ \\
\cline { 2 - 3 } & Using laboratory in lesson & Laboratory status at school \\
\cline { 2 - 3 } & Expectations for ideal laboratory set-up & $\begin{array}{c}\text { Accessibility of materials } \\
\text { Visuals on the walls } \\
\text { Specially trained laboratory teacher }\end{array}$ \\
\cline { 2 - 3 } & Teacher's laboratory training & $\begin{array}{c}\text { Pre-service training } \\
\text { In-service training } \\
\text { No training }\end{array}$ \\
\cline { 2 - 3 } & Benefits of experimenting in Science & $\begin{array}{c}\text { Benefits for teachers } \\
\text { Benefits for students }\end{array}$ \\
\cline { 2 - 3 } & Safety measures in laboratory & $\begin{array}{c}\text { Warnings for materials } \\
\text { Support tools (gloves, glasses, and so on) } \\
\text { Teacher supervision }\end{array}$ \\
\hline
\end{tabular}

\subsection{Teaching Science Lesson}

As a result of the analyses, it was emerged that different applications were used at the point of processing of the science course. The categories formed under the sub-themes of the "teaching science lessons" were experimenting in the class, using the software, watching experiment videos from the internet, and using textbooks. Direct quotations from the participants' views were presented as below:

\subsubsection{Experimenting in Class}

"We generally teach science lessons with verbal expressions. But if we can, we are trying to do simple little experiments in the classroom."(İbrahim Teacher)

\subsubsection{Using the Software (Morpa, EBA, and so on)}

"We have mostly used 'Morpa Campus' site. There are experiments on some subjects. There is Hanife teacher, she is doing experiments. They understand better when they see it visually. We have a way like this." (Barış Teacher)

"There is no laboratory at school, so sometimes students bring stuff from home in simple experiments and we do experiments in the classroom. But, we mostly use Morpa and Eba software. Curriculum-based experiment videos are available in these software programs. We have the students watch the videos; this enables them to see the experiment" (Hakan Teacher).

\subsubsection{Watching videos from the Internet}

"Since our school has moved to a new building, we have no more laboratory setup here. We are watching the experiments on the internet taking advantage of certain things."(Ayşe Teacher)

\subsubsection{Teaching Lesson from Textbook}

"I use the textbook as a standard. The book already has the necessary knowledge. It is at the level that children can understand. If they are at a higher level, the children can already have a problem. Those experiments that my book has given me are enough for me, that I see it. Therefore, I use the textbook in my lessons." (Merve Teacher)

Most participants indicated that they rarely conducted any experiments in class. Although a few participants indicated that they sometimes conducted simple experiments in class, most of them relied on the Morpa campus site or the internet to watch experiments on screen. Few students were engaged in hands-on activities because of the absence of laboratory facilities. Teachers' views emphasized that science courses were mainly based on the use of books or the Internet and software. Even though experiments were performed sometimes, although rare, they were performed in the classroom environment. It is also noteworthy that these experiments were not performed at the end of a research or an exploration process, but instead they are strictly dependent on the book.

In Turkey, EBA (Education Informatics Network) which belongs to the Ministry of National Education and the popular remote education platforms named Morpa Campus and Okulistik, which are approved by the Ministry, are the environments where teachers can get free access. Generally teachers prefer using of the available platforms and making the students watch the videos on the Internet than doing or having the students do the experiments themselves in science classes. It can also be said that science classes are taught in this way because of the physical conditions of the school are inadequate and there is a risk of going beyond the level of the students.

\subsection{Using Laboratory in Lesson}

In science classes, using the laboratory depends on the laboratory status at school. When this category (laboratory status at school) is analyzed, it is seen that there are no laboratories at some schools, using of materials in the store for science experiments and the 
borrowing of materials from other schools as sub-categories. Explanations of the participants about these situations are as follows:

\subsubsection{Laboratory Status at School}

- No laboratory at school

"It has to be a laboratory. But, there is not a laboratory in our school. I think that it is really important for the children to have a laboratory in elementary school as well as to see it in that department." (Ali Teacher)

- Use of materials in the archive (or depot)

"There is a material room but everything is complicated. For example if I need a beaker or spirit lamp for a lesson, I am trying to find it in this restricted place. I try to manage with them." (Ahmet Teacher)

- Requesting materials from the sub-school

"So, we do not have a lab as an opportunity. We do not have laboratories, but we can request materials from the secondary school if necessary." (Barış teacher)

"We have no science laboratory in our school, there is a laboratory in the secondary school, with which we share the same garden. We do not have the chance to use that laboratory because their students use it. If we can get the materials they are not using on a particular day, then we can do the experiment in our own classroom environment, but this is a rare situation." (Sibel Teacher)

When the primary education (8 years) has been divided into two in our country as the primary school and secondary school, the physical conditions of the schools have changed, as well. The laboratories have been mostly assigned to the use of secondary school buildings, as a result of which many primary schools have to continue education in buildings which do not have a laboratory. This is a problem even in central (higher socioeconomic level) schools. Hence it could be stated that teachers who would like to do experiments fail to teach science classes as needed due to the lack of materials and environment arising from this problem.

\subsection{Expectations for Ideal Laboratory Set-up}

The participants described the characteristics of the science laboratories in their dreams (the ideal ones). The categories arisen in this context are the availability of materials, the presence of visuals on the walls, and the specially trained lab teacher. Direct quotations from participants' views on these categories are as follows:

\subsubsection{Accessibility of Materials}

"Children should be able to access the materials in the laboratory very easily, for example, at the beginning of the tables, there should be a place where the laboratory supplies are located. The table should be a bit wider and slightly different from the normal desk so that the children can work on it. It should also be appropriate for the size of children." (Ayşe teacher)

"We are used to organizing the materials at high locations in fear that students could drop and break them. And, they are generally locked in glass containers. But, the materials should actually be at locations that are easy to access by the students, so that they can touch and explore them on their own. Of course, after the safety condition... " (Deniz Teacher)

\subsubsection{Visuals on the Walls}

"If I had a lab in the school, I would pay great attention to the visuals. I took care to have visuals about the experiments at primary school level." (Güzide Teacher)

"When children come into class, there must be pictures on the walls that can draw their attention to the science lesson." (Esma Teacher)

\subsubsection{Specially Trained Laboratory Teacher}

"The school must have a laboratory teacher. Every teacher should make an appointment for the experiment and he must prepare all the materials. The children should do their experiments with that teacher." (Zehra Teacher)

Teachers' views suggest that they would like to have a laboratory in their school. They would like this laboratory to be designed in a way that would allow for student-centered applications. It can be considered that while the participants experience difficulties in practice, they attach importance to learning by hands-on activities in comparison to the traditional approach based on memorization and believe in the necessity of exploration by the child.

\subsection{Teacher's Laboratory Training}

The categories emerged in the analysis of interviews about teachers' laboratory training are pre-service, in-service transcribed, and no training. The sections of the participants' explanations in this context are:

\subsubsection{Having Pre-service Lab Training}

- Taking laboratory lessons in classroom teacher's undergraduate program

"I am a class teacher. Practically, I had a laboratory course at education faculty, but I cannot remember the exact name. However, I had the course in a term."(Sevim Teacher)

- Taking lab lessons while studying in a different undergraduate program

"I am a graduate physics teacher. This situation brought an advantage to me when I was appointed as a classroom teacher. I graduated from the department of physics and so I took many lab courses "(İbrahim Teacher)

\subsubsection{Having In-service Lab Training}


"I also attended a course on science experiments and the use of laboratory equipment both during and after my studies at the university, and I also received the course document. This course lasted about three months." (Zehra Teacher)

"I started my profession at a school in an Eastern village. I used to go to the city center at the weekends to attend an in-service training which took a month. It was a theoretical and applied course on laboratory." (Ahmet Teacher)

\subsubsection{The Ones not Having Science Lab Training}

"I graduated as a French teacher. I was appointed as a class teacher, but not in my own field. Therefore, I did not take any courses, and I did not attend any courses." (Merve Teacher)

This research revealed the fact that as teachers who had studied different branches (like Physics, Chemistry, Social Sciences, Foreign Language, and so on) were appointed as classroom teachers for long years, some teachers had not received any course about laboratory before starting their profession while some others were quite advantaged as they had graduated from Science school. It is important to note that the teachers receiving no education about laboratory received in-service training to overcome their deficiencies while some others have laboratory experience neither before starting the profession nor as an in-service training. This diversity among the teachers makes suggests that the emergence of inadequacy and problems in the use of laboratory in science classes is quite natural.

\subsection{The Benefits of Experimenting in Science}

When the participants' views on the benefits of experimenting in the science class were analyzed, two basic categories of benefits for teachers and students emerged. From the point of view of the teacher, there were categories where the lessons were easier and there was more fun to work with students for teachers, and experimenting in science supported the science process skills of the students and also permanence of them. Direct quotations taken from participants' views on these categories are as follows:

\subsubsection{Benefits for Teachers}

- The course is enjoyable

"In terms of the teacher, course becomes even more enjoyable with experiments, of course, the teacher is more pleasurable, and as the teacher tries to do different things (experiments), the teacher becomes more willing as he enjoys it." (Aslı Teacher)

"As I am a classroom teacher with a background in Physics teaching, I feel happy to do experiments in Science classes. I enjoy those classes just like the students." (İbrahim Teacher)

- The course is taught more easily
Eyüp teacher says that "experimenting relaxes and also rests the teacher and it makes the understanding of the course subjects easier more often than to repeat."

"Doing experiments enables materialization of the subjects and avoiding memorization and ensures learning by experimenting and experiencing. Thus, children learn easier." (Ali Teacher)

\subsubsection{Benefits for the Students}

- It maintains experiments enhance the retention of scientific learning

"We use the repeating technique without experiment, but a child cannot learn, but when you build a simple experiment, the child actually holds it and there is no need for a second one. Then she recalls it easily."(Ayşe Teacher)

- Science Process Skills is developing

"A student can carry himself one step beyond the experiment. For example, he thinks if I do this experiment, I can make a different conclusion from that experiment.”(Mustafa Teacher)

- It provides learning through experience

"We also have students who can learn through experience. So, they will learn, touch, and do. This is very helpful for our children. So, they surely want it. Practical learning is very important for these children. They have to reach the end with the experiments they have done." (Merve Teacher)

Most of the research participants stated that they rarely did experiments in science classes, they read the subject from the course book and narrated, and they preferred to have the students watch the steps of an experiment through online platforms. Yet, the participants interestingly believed that experimenting is useful both for the students and themselves. This suggests that although the teachers believed experimenting to be useful for the students, they do not benefit from this useful process due to the aforementioned issues.

\subsection{Safety Measures in the Laboratory}

The participants put an emphasis on taking security precautions during the use of the laboratory at primary school level. The categories specified in the subclasses of safety in the laboratory are the use of warnings for the materials, the use of support tools (gloves, glasses, and so on), and the increase of teacher supervision. Sections of the participants' explanations within the context of these categories are:

\subsubsection{Using Warnings for the Materials}

"Children should be careful when using cutting and flammable appliances. There are a few harmful materials in the laboratory environment. Although the child knows 
that it is harmful to touch it, they touch because the children are curiosity." (Veli Teacher)

"I prefer my students to reach the materials easily because we don't have any experiment in primary level that students get problems about it. So, I only want my students to be careful when they touch glass materials and spirit lamb." (Deniz Teacher)

\subsubsection{Using Support Tools (Gloves, Glasses, and so on)}

"They need to use gloves. If you are working with a flammable substance, you should use glasses and gloves (I do not know how suitable for the situation) but the first things that come to mind are glasses, gloves and also lab coats which can be used as a precaution." (Sultan Teacher)

\subsubsection{Increasing Teacher Supervision}

"If heating needs to be done, this can be done under the supervision of the teacher, but students do not do it alone. For example, if there is a heating experiment, the heating is going to be done with the teacher." (Mehmet Teacher)

While most of the participants stated that they did not use any science laboratory at primary school due to several reasons, they thought that safety is an important issue in laboratory, and they believed in the necessity of taking measures. They thought that attention should be paid to materials that may cause harm. This sensitivity of the teachers (although they were not able to use the laboratory) can be due to the affective elements brought by the profession of teaching (like positive attitude toward the profession, love of children, and so on).

\section{Conclusions and Discussion}

At the end of the research, it became clear that different applications were the subject of the science course at the primary school. When the lessons were being processed, it is common practice that the experiment was done in the classroom due to the lack of laboratory or lack of it, the software is used in the lessons, the videos of the experiment are watched from the internet and the text book has been processed in the science course. It has been stated that the science laboratories have a very important function when the science courses are actively carried out ([3]). Similarly, it has been stated that it is important that using simple tools and instruments in classrooms is better than never using laboratories in science courses ([29]).

It is pointed out that some troubles were in the way of using the laboratory in science course. Some of the class teachers stated that there was no science laboratory in the schools, but some of them stated that because some materials were available even though they had not got laboratories but that they are forced to use the materials actively because they were in the storage rooms. When there is no science laboratory in the primary school, but it is found in the secondary school in the same school garden, borrowing material is requested from there and it turns out that the experiments are carried out with these tools in science class. Similarly, in a study conducted by [30], most of the teachers stated that there is also a science laboratory in their school but the equipment in the laboratory is inadequate. In the study conducted by [31], it has been concluded that the biggest obstacles of science and technology teachers about experimenting and using the laboratory are the inadequate materials in the schools and the limited hours of lessons determined by the program. In the study conducted by [32], it is emphasized that teachers are aware of the importance of laboratory equipment, but that laboratory equipment is inadequate and used at a limited level. Likewise, in the research conducted by[33], it is stated that lack of sufficient equipment in laboratories prevents students from learning at the desired level.

In the light of research, the teachers wanted to work in primary school in the context of the properties of the laboratory that the materials are available; the relevant images are on the walls and the presence of the responsible laboratory teacher in the science laboratories.

In the current study, some of the class teachers received laboratory lessons during their undergraduate education, some of them received in-service training after they started to work, and some of them were trained as science teachers in different branches. Teacher training shall encourage the teacher candidates to understand the nature of practice and help them use these activities in their classes in the future [5]. In the study conducted by [34], it is stated that teachers generally find themselves adequate in carrying out their laboratory practices.

In the current study, it had been revealed that laboratory practices (doing experiments) in both science and science classes in elementary school bring contributions for both student and teacher. When it comes to the benefits of the teacher in terms of laboratory practices, it is achieved that the course subjects are easier and the lesson has more fun. In the light of findings obtained from the opinions of the class teachers, experimentation in science lessons offers advantages to the students both by providing the permanence of the learned subjects and by supporting the development of science process skills, thereby enabling them to learn through experience. Studies conducted by [35], have shown that experiments in the science laboratory have resulted in a positive attitude of the students towards the science laboratory. In the study conducted by [36], it is noted that laboratory practices have improved student problem-solving skills. In a different study conducted by [37], it is stated that laboratory practices are effective for students to gain a scientific perspective. Furthermore, based on their findings arising from teachers' views, it is claimed that laboratory practices enable effective, permanent and enjoyable learning [5]. 
In the current research, it is stated that safety measures must be taken during the laboratory practices in primary school. Safety precautions should be taken in the laboratory. Using of a number of tools for safety (gloves, goggles, and so on), and the enhancement of teacher supervision in the laboratory had been emphasized by teachers. Similarly, in the study conducted by [38], it is stated that careful planning and regulation of the various hazards that may be involved in laboratory studies are required.

Based on the results obtained, the following suggestions can be made:

The laboratory facilities of the schools should be increased.

Practical in-service training should be given to teachers from outside the field on the use of laboratories in science classes.

Laboratories should be made suitable for elementary school children in terms of tools and materials.

In the future research, quantitative researches can be designed and the situation of the laboratory facilities across the country can be revealed, and necessary measures should be taken in the light of the results obtained.

\section{Acknowledgements}

This study is a part of the project of "17.KARIYER.101", supported by Afyon Kocatepe University, Scientific Research Projects Coordination Unit, and it was presented as an oral presentation at the $4^{\text {th }}$ International Conference on Primary Education (IPECONF-2017).

\section{REFERENCES}

[1] Hançer, A. H., Şensoy, Ö., \& Yıldırım, H. İ. (2003). İlköğretimde Çağdaş Fen Bilgisi Öğretiminin Önemi ve Nasıl Olması Gerektiği Üzerine Bir Değerlendirme [An Evaluation about the Importance of Contemporary Science Education at Elementary Schools and How This Kind of Science Teaching Must Be]. Pamukkale University Journal of Education 13(13), 80-88.

[2] Ministry of National Education (MoNE) (2017). Elementary School Science Curriculum (Grades for 3-8). http://mufredat.meb.gov.tr/ProgramDetay.aspx?PID=143. Erişim tarihi: 12 Kasım 2017.

[3] International Council for Science [ICSU] (2011). Report of the ICSU, Ad-hoc Review Panel on Science Education. International Council for Science, Paris, Accessed: 26.11.2017, At: http://www.icsu.org/publications/report.pdf

[4] Cullin, M., Hailu, G., Kupilik , M. \& Petersen, T. (2017). The Effect of an Open-Ended Design Experience on Student Achievement in an Engineering Laboratory Course.
International Journal of Engineering Pedagogy. 7(4), 102-116.

[5] Harman, G. Cokelez, A. Dal, B. \& Alper, U. (2016). Pre-service Science Teachers' Views on Laboratory Applications in Science Education: The Effect of a Two-semester Course. Universal Journal of Educational Research 4(1): 12-25.

[6] Kwok, P.W. (2015). Science laboratory learning environments in junior secondary schools. Asia-Pacific Forum on Science Learning and Teaching. 16(1), 1-28.

[7] Tekin, S., Sağır, Ş.U. \& Karamustafaoğlu, S. (2012). Sınıf Öğretmeni Adaylarının Fen Bilgisi Laboratuvar Uygulamalar1-1 Dersi Kazanımlarının Kimya Deneyleri Açısından İncelenmesi [Examining the Science Laboratory Applications - 1 Skills of Classroom Teachers Depending on Chemistry Experiments]. Pamukkake University Journal of Education, 31, 163-174.

[8] Staeck, L. (1995). Perspectives for Biological Education Challenge for Biology Instruction at the End of the 20th Century, Hacettepe University Journal of Education, 11, 29-35.

[9] Hofstein, A. \& Lunetta, V.N. (1982). The role of the laboratory in science teaching: Neglected aspects of research. Review of Education Research, 52 (2): 201-217.

[10] Osborne, J. (1998). Science education without a laboratory? In J. Wellington (Ed.), Practical work in school: which way we now? (pp.156-173). London and Newyork: Routledge.

[11] Freedman, M.P. (1997). Relationship among laboratory instruction, attitude toward science, and achievement in science knowledge. Journal of Research in Science Teachıng. 34(4), 343-357.

[12] Wellington, J. (1998). Practical Work in Science: Time for a Re-appraisal. Practical Work in School. In J. Wellington (Ed.), Practical Work in School: Which Way We Now? (pp.3-15). London and Newyork: Routledge.

[13] Madhuri, G. V., Kantamreddi, V. S. S. N., \& Prakash-Goteti. L. N. S. (2012). Promoting higher order thinking skills using inquiry-based learning. European Journal of Engineering Education, 37(2), 117-123. http://dx.doi.org/10.1080/03043797.2012.661701

[14] Wilcox, B.R. \& Lewandowski, H.J. (2016). Open-ended versus guided laboratory activities: Impact on students' beliefs about experimental physics. Physical Review Physics Education Research. 12 (2016), 1-8.

[15] Chin, C. \& Kayalvizhi, G. (2002). Open-Ended Investigations In Science: A Case Study Of Primary 6 Pupils. Journal of Science and Mathematics Education in S.E. Asia. 25(1), 25-94.

[16] Feyzioglu, B., Demirbag, B., Ates, A., Cobanoglu, I. \& Altun, E. (2011). Chemistry Teachers' Perceptions on Laboratory Applications: Izmir Sample. Educational Sciences: Theory \& Practice . 11(2), 1024-1029.

[17] Berg, C.A.R., Bergendahl, V.C.B., Lundberg, B.K.S. \& Tibell, L.A.E. (2003). Benefiting from an open-ended experiment? A comparison of attitudes to, and outcomes of, an expository versus an open-inquiry version of the same experiment. International Journal of Science Education, 
25(3), 351-372.

[18] Szott, A. (2018). Open-ended Laboratory Investigations in a High School Physics Course: The difficulties and rewards of implementing inquiry-based learning in a physics lab. The Physics Teacher 52, 17 (2014); https://doi.org/10.1119/1.48 49147.

[19] Bolong, N., Makinda, J. \& Saad, I. (2014). World Academy of Science, Engineering and Technology International Journal of Social, Behavioral, Educational, Economic, Business and Industrial Engineering 8(8), 2554-2558.

[20] Hodson, D. (1990). A critical look at practical work in school science. School Science Review, 70(256), 33-40.

[21] Creswell, J.W. (2015). Nitel Araștırma Yöntemleri- Beş Yaklaşıma Göre Nitel Araştırma ve Araştırma Deseni. (Qualitative Inquiry and Research Design: Choosing Among Five Approaches). (Mesut Bütün; Selçuk Beşir Demir, Translation Ed.). Ankara: Siyasal Kitabevi.

[22] Christensen, L. B., Johnson, R. K. \& Turner, L. A. (2015). Research methods, design and analysis. (Aypay, A. Translation Ed.). Ankara: An1 Publishing.

[23] Creswell, J. W. (2012). Educational research: planning, conducting, and evaluating quantitative and qualitative research. $4^{\text {Th }}$ Ed. USA: Pearson Ed. Inc.

[24] Richards, L., \& Morse, J. M. (2007). Read me first for a user's guide to qualitative methods (2nd Ed.). Thousand Oaks: Sage.

[25] Ersoy, A. (2014). İnternet Kaynaklarından İntihal Yaptığımın Farkında Değildim: Bir Olgubilim Araştırması [I Was Not Aware I Plagiarized From Online Resources: A Phenomenological Research], Pamukkake University Journal of Education, 35(1), 47-60.

[26] Merriam, S. B. (2013). Qualitative research:A guide to design and implementation (S. Turan, Translation Ed.). Ankara: Nobel Publishing.

[27] Miles, M. B. \& Huberman, A. M. (1994). Qualitative data analysis: an expanded sourcebook. (2nd Edition). Calif. : SAGE Publications.

[28] Creswell, J. W. \& Plano Clark, V. L. (2014). Karma yöntem araştırmaları: Tasarımı ve yürütülmesi. (Designing and Conducting Mixed Methods Research). (Yüksel Dede, Selçuk Beşir Demir \& A. Delice, Translation Ed.). Ankara, Türkiye: Anı Yayınc1lık.

[29] Sarı, M. (2011). İlköğretim Fen ve Teknoloji Derslerinin Öğretiminde Laboratuvarın Yeri ve Basit Araç-Gereçlerle Yapılan Fen Deneyleri Konusunda Öğretmen Adaylarının Görüşlerinin Değerlendirilmesi [The Importance of Laboratory Courses In Science And Technology Teaching in Primary Education And The Ideas of Simple Tools and Instruments to Evaluate Teacher Candidates on Science Experiments]. 2nd International Conference on New Trends in Education and Their Implications, 27-29 April. Antalya-Turkey.

[30] Yıldız, E., Akpınar, E., Aydoğdu, B. \& Ergin. Ö. (2006). Fen Bilgisi Ögrretmenlerinin Fen Deneylerinin Amaçlarına Yönelik Tutumları [Science Teachers' Attitudes Towards the Purposes of Science Experiments]. Journal of Turkish Science Education, 3 (2), 2-18.
[31] Demir, S., Böyük, U. \& Koç, A. (2011). Fen ve Teknoloji Dersi Öğretmenlerinin Laboratuvar Şartları ve Kullanımına İlişkin Görüşleri ile Teknolojik Yenilikleri İzleme Eğilimleri. [Opinions of Science and Technology Teachers about Laboratory Conditions and Usage and Trends in Monitoring Technological Innovations]. Mersin University Journal of the Faculty of Education, 7(2), 66-79.

[32] Küçüköner, Y. (2010). The relationship of using laboratory tools and equipments in eight grade science and technology courses with outputs aimed by Ministry of Education, and analysis of teacher views towards these tools and equipments (Bingol sample). (Unpublished master's thesis). Erzincan University Graduate School of Science, Erzincan.

[33] Ayas, A., Karamustafaoğlu, S., Sevim, S. \& Karamustafaoğlu, O. (2002). Genel Kimya Laboratuar Uygulamalarının Öğrenci Ve Öğretim Elemanı Gözüyle Değerlendirilmesi. [Academicians' and Students' Views of General Chemistry Laboratory Applications]. Hacettepe University Journal of Education, 23, 50-56.

[34] Akdemir, Ö. (2006). Competency of secondary school science teachers in laboratory practices and the problems they face with applications (Unpublished master's thesis). Firat University Graduate School of Social Sciences, Elazığ.

[35] Yeşilyurt, M., Kurt, T. \& Temur, A. (2005). İlköğretim Fen Laboratuvarı için Tutum Anketi Geliştirilmesi ve Uygulanmas1 [Development and Application of Attitude Questionnaire for Primary Science Laboratory]. Pamukkake University Journal of Education, 17: 23-37.

[36] Hofstein, A. (2004). The laboratory in chemistry education: thirty years of experience with 13. Developments, implementation, and research. Chemistry Education: Research and Practice. 5(3), 247-264.

[37] Orbay M., Özdoğan T., Öner F., Kara M. \& Gümüş S. (2003). Fen bilgisi laboratuvar uygulamaları I-II dersinde karş1laş1lan güçlükler ve çözüm önerileri [Difficulties encountered in science lab laboratory applications I-II lesson and solution proposals]. Journal of National Education, 157.

[38] Hamurcu, H. (1998). Fen Derslerinde Güvenlik [Security in Science Course]. Hacettepe University Journal of Education. 14: 29-32. 